\title{
Seasonal and spatial variations in limnological conditions of a floodplain lake (Lake Catalão) connected to both the Solimões and Negro Rivers, Central Amazonia
}

\author{
Janaina Gomes de BRITO ${ }^{1, *}$, Luiz Fernando ALVES ${ }^{2}$, Helder Mateus Viana ESPIRITO SANTO ${ }^{3}$ \\ Programa de Pós-Graduação em Entomologia, Coordenação de Biodiversidade, Instituto Nacional de Pesquisas da Amazônia - INPA. Av. André Araujo, 2936, CP 478, \\ CEP: 69067-375. Manaus, Amazonas, Brasil \\ * Corresponding Author: janaina.gomesdebrito@gmail.com \\ 2 Coordenação de Biodiversidade, Instituto Nacional de Pesquisas da Amazônia - INPA. Manaus, Amazonas, Brasil. lalves@inpa.gov.br \\ 3 Programa de Pós-Graduação em Ecologia, Coordenação de Biodiversidade, Instituto Nacional de Pesquisas da Amazônia - INPA. Manaus, Amazonas, Brasil. espiritosantohm@gmail.com
}

\section{ABSTRACT}

Lakes play an important role in biogeochemical, ecological and hydrological processes in the river-floodplain system. The aim of this study was to evaluate the dynamics of the limnological conditions of Cataláo Lake, an Amazon floodplain lake. Thus, some of the main limnological environment variables $\left(\mathrm{O}_{2}\right.$, temperature, $\mathrm{pH}$, nutrient, electrical conductivity) of the Cataláo Lake were analyzed under temporal and spacial scales. The study was conducted between November/2004 and August/2005. Sampling excursion were carried out every three months; one excursion for each of the four different hydrological periods (low water, rising water, high water and falling water). Sampling points were chosen so that it could be obtained a gradient of the distance from Negro River. Limnological profiles in Catalão Lake showed generally acidic to slightly alcaline water, with low levels of dissolved oxygen and low concentrations of soluble reactive phosphorous. The Negro River seems to exert the main influence during the rising water period, while the Solimóes River is the principal controlling river during peak water. The Principal Component Analysis (PCA) grouped the seasonal collections by hydrological period, showing the formation of a north-south spatial gradient within the lake in relation to the limnological variables. Multivariate dispersion analysis based on distance-to-centroid method demonstrated an increase in similarity over the course of the hydrological cycle, as the lake was inundated in response to the flood pulse of the main river channels. However, the largest spatial homogeneity in the lake was observed in the epilimnion layer, during the falling water period. The daily analysis of variation indicated an oligomitic pattern during the years in which the lake was permanently connected to the Negro River. Although Cataláo Lake receives large quantities of both black water from the Negro River and sediment-filled water from the Solimóes River, the physical and chemical characteristics of the lake are more similar to those of the Solimóes (várzea lake) than the Negro (blackwater lake).

KEYWORDS: Hydrological regime, water quality, chemical limnology.

\section{Variações espaciais e temporais nas condições limnológicas de um lago de planície de inundação (lago Catalão) conectado aos rios Solimões e Negro, Amazônia Central}

\section{RESUMO}

Os lagos exercem um papel importante nos processos biogeoquímicos, ecológicos e hidrológicos no sistema rio-planície de inundação. O objetivo do presente estudo foi avaliar a dinâmica das condiçóes limnológicas do lago Catalão, um lago da planície de inundação amazônica. Algumas das principais variáveis limnológicas (por exemplo, $\mathrm{O}_{2}$, temperatura, $\mathrm{pH}$, condutividade elétrica, nutrientes) do lago Cataláo foram analisadas em uma escala temporal e espacial. O presente estudo foi realizado no período de novembro de 2004 a agosto de 2005. As amostragens foram trimestrais, com um total de quatro coletas, uma em cada fase do ciclo hidrológico (Seca, Enchente, Cheia e Vazante). Os pontos de amostragem foram escolhidos de modo a obter um gradiente de distância em relação ao rio Negro. No geral, as águas do lago Catalão mostraram-se pouco oxigenadas, ácidas a levemente alcalinas e com baixas concentrações de Fósforo Solúvel Reativo (FSR). A Análise de Componentes Principais (ACP) agrupou as estaçóes de coleta por fases do ciclo hidrológico e evidenciou a formaçáo de um gradiente espacial na distribuição das variáveis limnológicas, que vai da região mais ao norte até mais ao sul do lago. A influência do rio Negro sobre as águas do lago parece ser maior na enchente e a do rio Solimóes na cheia. A análise de dispersão multivariada com abordagem baseada na distância ao centróide evidenciou o aumento da similaridade espacial em função da inundação. Contudo, a maior homogeneidade espacial do lago foi registrada no epilímnio, na fase de vazante. Os resultados da análise de variação diária indicaram que o lago Cataláo apresenta comportamento oligomítico nos anos em que permanece conectado permanentemente ao rio Negro. Apesar de receber grande aporte de águas pretas (rio Negro) e brancas (rio Solimóes), as características físicas e químicas das águas do Catalão permitem classificá-lo como um sistema mais próximo dos lagos de várzea típicos do que daqueles de águas preta.

PALAVRAS CHAVE: Regime hidrológico, qualidade da água, limnologia química. 


\section{INTRODUCTION}

Lakes play an important role in biogeochemical, ecological and hydrological processes in the river-floodplain system (Sippel et al. 1992; Melack and Forsberg 2001). For example, the Amazonas River floodplain within Brazilian territory covers an area of $92,400 \mathrm{~km}^{2}$, of which $11 \%$ are composed of lakes (Sippel et al. 1992). Floodplain lakes are considered highly productive systems (Junk and Welcomme 1990), playing an important role in nutrient recycling and retention processes (Melack and Fisher 1990), as well as providing habitat for a variety of fish, many of which have high economic value (Goulding 1980; Leite et al. 2006). Annually, owing to the monomodal hydrological regime of the main river channel and its tributaries the water volume and depth of floodplain lakes change, as well the extension of the flooded area (Junk 1997). During the high water period, due to the combination of fluvial influx, precipitation and overland flow, some floodplain lakes can reach depths beyond $10 \mathrm{~m}$, while during the low water period the same lakes often become shallow water bodies isolated from the main channel (Lesack and Melack 1995).

The annual flood pulse is considered the most predominant factor in controlling the limnological and biological changes observed in floodplain lakes (Junk et al. 1989). For example, the hydrological regime is considered to affect both seasonal (Thomaz et al. 1997) and spatial (Thomaz et al. 2007) variations in limnological parameters, while lake morphometry has been shown to present a direct relation to mixture regimes and water circulation (Tundisi et al. 1984; MacIntyre and Melack 1988; Panosso et al. 1995). However, it is important to note that the flood pulse influence varies with the distance and connection between the lake and the main river channel (Fantin-Cruz et al. 2008), and also in relation to the amplitude of the annual flood cycle. In some cases, lakes may be connected all year-round to the main channel, while in other situations the lake remains connected to the river only during part of the year.

Many different studies have focused on understanding how the flood cycle affects the physical, chemical and biological changes encountered in floodplain systems and associated lakes (e.g. Forsberg et al. 1988; Tockner et al. 1999; Townsend 2006). In limnological terms, Thomaz et al. (2007) described the homogenization effect of the hydrological regime on the flood cycle of floodplain lakes. According to these authors, fluvial influx tends to increase the limnological similarity between floodplain rivers and associated lakes, while periods of isolation tend to increase the differences.

In the present study, limnological conditions were studied in Lake Cataláo, a floodplain lake situated between the muddy Solimóes River and the blackwater Negro River. Lake Cataláo is fed by tributaries that are composed of water with different limnological characteristics. The turbid water of the Solimóes River carries a high sediment load, with electrical conductivity between 60-90 $\mu \mathrm{S} \mathrm{cm}^{-1}$ and $\mathrm{pH}$ between 6-7 (Furch 1984; Queiroz et al. 2009), while the Negro River is composed of acidic water rich in humic and fulvic substances, with electrical conductivity ranging between $7-10 \mu \mathrm{S} \mathrm{cm}^{-1}$ and $\mathrm{pH} \leq 5.5$ (Furch 1984; Darwich et al. 2005). Therefore, the waters of Lake Catalão are a changeable mixture of these two chemically distinct sources.

To better understand the spatial and temporal dynamics of limnological variables in the Lake Catalão, the following objectives were established: (a): Evaluate the limnological conditions of the four sampling stations located along a longitudinal gradient from the Negro River; (b): Identify seasonal patterns in limnological conditions of the waters of Lake Catalão (c): Verify the occurrence of a proportional and positive relation between limnological similarities in the lake and fluvial influx (change in water level); and (d): Describe the daily variations of the most important limnological variables during different phases of the hydrological cycle.

\section{MATERIALS AND METHODS}

\section{Study area}

Lake Cataláo (Figure 1) is situated in a floodplain area at the confluence of the Negro River with the Solimóes River, located near to the city of Manaus, Amazonas State, Brazil $\left(3^{\circ} 10^{\prime} 04^{\prime \prime} \mathrm{S} ; 59^{\circ} 54^{\prime} 45^{\prime \prime} \mathrm{W}\right)$. Due to its close proximity to both rivers, Lake Catalão is flooded periodically by both the sediment-filled Solimóes and blackwater Negro rivers, receiving large quantities of water and solutes. The connection with these different fluvial systems varies annually, alternating between permanent connectivity with at least one of the rivers (the Negro River), and periodic isolation from both systems.

Geologically, the lake is situated in an area of Quaternary sediments, represented by alluvial deposits of Andean and preAndean origins (Junk and Furch 1980; Sioli 1984).

\section{Field sampling and data analysis}

The study was conducted between November/2004 and August/2005. Sampling excursion were carried out every three months; one excursion for each of the four different hydrological periods (low water, rising water, high water and falling water), which differed in terms of water level and direction of flow. During the low water (November), the water was at its lowest level, while maximum amplitude was reached at the peak high water stage (July). During the rising water period (March), the direction of water flow was from the rivers to the lake, which gradually increased the water depth of the lacustrine system. Conversely, during the falling water period (August), lake depth decreased as the direction of water flow inverted, with water draining to the rivers. 


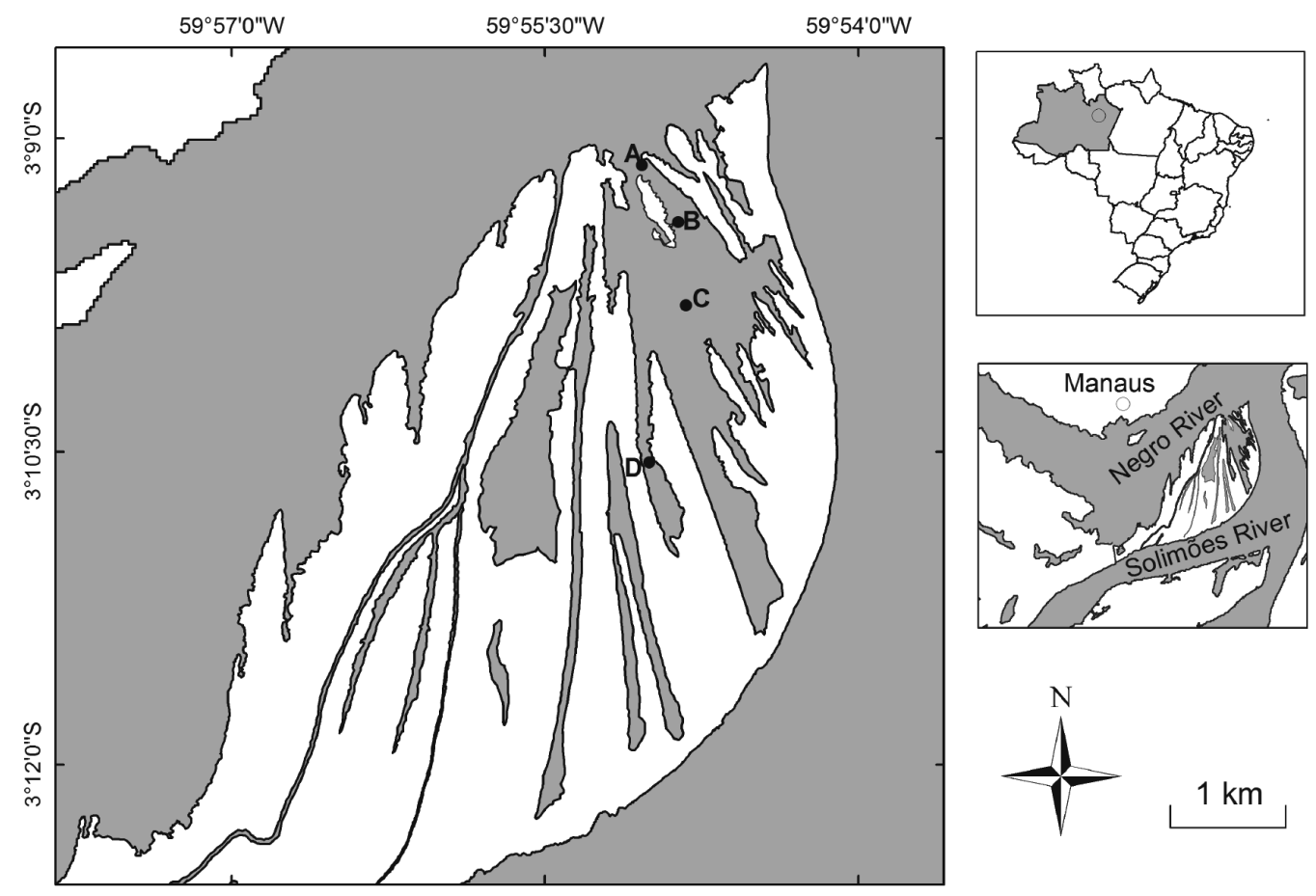

Figure 1 - Geographic localization of Lake Catalão (Manaus, AM). The letter A, B, C and D indicate the sampling points.

Sampling periods were scheduled to coincide with seasonal variations in the hydrometric level of the Negro River (Figure 2), which remained connected to the lake during the entire period of this study.

The samples were collected at four points along the length of the lake (Figure 1; Table 1). The sampling points were chosen along a distance gradient from the Negro River, with the northernmost point closest to the Negro River and the southernmost point closest to the Solimôes River, with two other points in between.

Profiles of water temperature (T), electrical conductivity (Cond), $\mathrm{pH}$ and dissolved oxygen (DO) at each point were determined every $0.5 \mathrm{~m}$ from the surface to the bottom using portable field meters (ProfiLine Oxi 197, pH 197 and Cond. 197, Wissenschaftlich-Technische-WerkstättenWTW, Weilheim, Germany). Water samples for physical and chemical analyses were collected at the sub-surface level $(0-0.5 \mathrm{~m})$ and close to the lake bottom using a Ruttner bottle. Chemical (COD) and biological (BOD) oxygen demand were determined by potassium permanganate oxidation and by the Winkler method respectively, following methodology described by Golterman et al. (1978). Total $\mathrm{CO}_{2}$ and alcalinity $\left(\mathrm{Al} ; \mathrm{HCO}_{3}^{-}\right.$) were measured by potentiometric titration, following Golterman et al. (1978). Total suspended solids (TSS) was determined gravimetrically, following the technique described by Bense et al. (1963). Cation concentrations of sodium $\left(\mathrm{Na}^{+}\right)$, potassium $\left(\mathrm{K}^{+}\right)$, calcium $\left(\mathrm{Ca}^{2+}\right)$ and magnesium $\left(\mathrm{Mg}^{2+}\right)$ were measured by atomic absorption spectrometer (Model 1100B; Perkin Elmer, Massachusetts, USA) in filtered samples. Concentrations of $\mathrm{N}$-nitrite $\left(\mathrm{NO}_{2}^{-}\right), \mathrm{N}$-nitrate $\left(\mathrm{NO}_{3}^{-}\right)$, soluble reactive phosphorous (SRP), soluble reactive silica (SRSi) and chlorophyll a (chla a; extraction with 90\% acetone) were analyzed following Golterman et al. (1978) and ammonia $\left(\mathrm{NH}_{4}\right)$, following Koroleff (1970). The mixture zone (Zmix) was estimated following Naselli-Flores (2000). Water transparency was measured by the extinction coefficient using a Secchi disk $(\mathrm{Sd})$, while the change in water depth $\left(\Delta_{\mathrm{pf}}\right)$ was determined with the aid of a graduated measuring stick.

In order to evaluate the daily changes of limnological variables in the lake, four daily cycles were conducted (one for each hydrological period) at site C (Figure 1). The measurements were taken in depth intervals of $0.5 \mathrm{~m}$ from the water surface to the lake bottom every three hours over a total of 24 hours.

Considering the large number of variables analyzed in this study, a principal components analysis (PCA) was applied with the objective to identify the variables that best explained the spatial and temporal (seasonal) variations of the data. For the study, the PCA was based on a correlation matrix. The dissimilarities were calculated based in the Euclidean 
distance after standardization of variables by its maximum value (Legendre and Legendre 1998). This ordination was conducted using the PAST 2.05 program (Hammer et al. 2001; free software).

To test the homogenization of limnological characteristics along the hydrological regime we used the multivariate dispersion approach based in distances to centroids (Anderson et al. 2006). The measure of dispersion was the distance from the collection points to a centroid in the multivariate limnological space. The lower mean dispersion within a hydrological period the higher homogeneity in the limnological features. The differences between the hydrological periods were then compared based in its means and confidence intervals. Our expectation was that the dispersion would be the highest in the low water period (low homogenization) and the lowest in the high water period (high homogenization). The centroids and the distances were calculated using the function betadisper in the library vegan (Oksanen et al. 2010) in the R statistical software (R Development Team 2010).

\section{RESULTS}

The waters of Lake Catalão are generally poorly oxygenated (2.4 $\mathrm{mg} \mathrm{L}^{-1}$; principally in the deepest layers where the most hypoxic levels were encountered), acidic to slightly alcaline (5.86-7.47) and with low concentrations of SRP $\left(28.9 \mu \mathrm{g} \mathrm{L}^{-1}\right)$. The low water, in comparison with the other hydrological periods, was characterized by higher alkalinity (52.8 $\mathrm{mgHCO}_{3}{ }^{-} \mathrm{L}^{-1}$ ) higher concentrations of ammonia (428.8 $\left.\mu \mathrm{g} \mathrm{L}^{-1}\right)$ and phytoplankton biomass $\left(19.1 \mu \mathrm{g} \mathrm{L}^{-1}\right)$, lower water transparency $(0.6 \mathrm{~m})$ and shallower depths $(2.5-11 \mathrm{~m})$. The rising water period presented lower values of cations $(\mathrm{Mg}: 0.6$ mg L ${ }^{-1}$, Ca: $1.7 \mathrm{mg} \mathrm{L}^{-1}$, Na: $\left.1.1 \mathrm{mg} \mathrm{L}^{-1}\right)$, SRSi $\left(1.8 \mathrm{mg} \mathrm{L}^{-1}\right)$, conductivity $\left(30.1 \mu \mathrm{S} \mathrm{cm} \mathrm{cm}^{-1}\right)$, alkalinity $\left(15.3 \mathrm{mgHCO}_{3}^{-} \mathrm{L}^{-1}\right)$, $\mathrm{pH}(6.3)$ and higher water transparency $(1 \mathrm{~m})$. At peak water,

Table 1 - Description of sampling points in Lake Catalão with respective GPS coordinates.

\begin{tabular}{|c|c|c|c|}
\hline Periods & \multicolumn{2}{|c|}{ GPS Coordinates } & Site description \\
\hline C & $03^{\circ} 09^{\prime} 47.9^{\prime \prime S}$ & $59^{\circ} 54^{\prime} 49.5^{\prime \prime} \mathrm{W}$ & Located in the middle and deepest part of the lake; \\
\hline $\mathrm{D}$ & $03^{\circ} 10^{\prime} 33.1 " \mathrm{~S}$ & $59^{\circ} 55^{\prime} 0.0^{\prime \prime} \mathrm{W}$ & $\begin{array}{l}\text { Located in the southern section of the lake, in the shallowest and most isolated part, which is bordered by } \\
\text { forest seasonally flooded by the Solimões River. }\end{array}$ \\
\hline
\end{tabular}

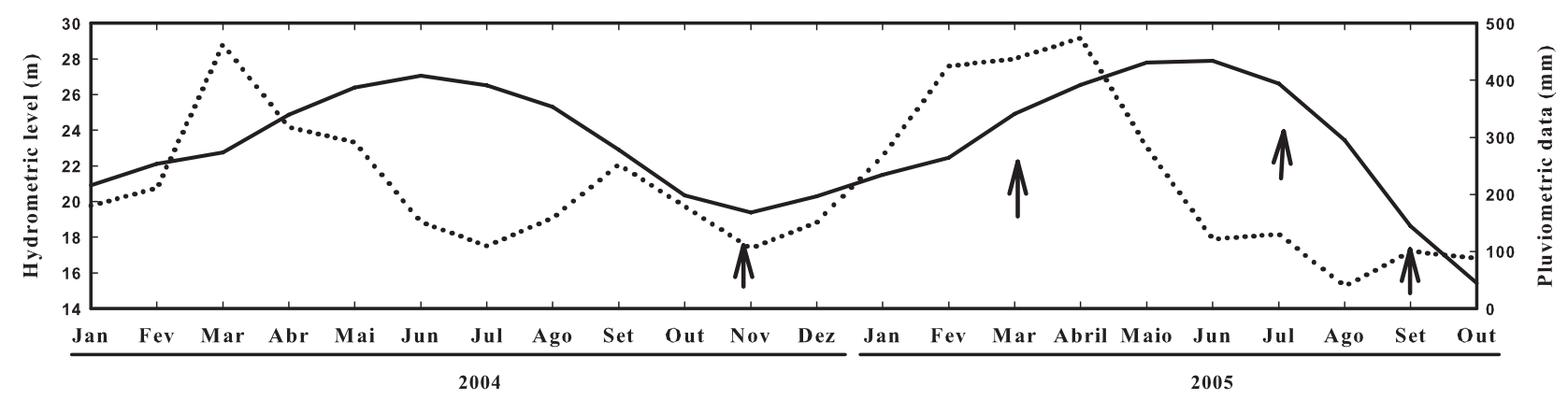

Figure 2 - Hydrometric level (solid line) of the Negro River and pluviometric data (dashed line) in the Manaus region from Jan/2004 and Oct/2005. The data was supplied by the Port Authority of Manaus and the Climate and Hydric Resource Department at INPA (National Institute of Research of the Amazon), respectively. Arrows represent the sampling periods. 
higher concentrations of $\mathrm{N}$-nitrate $\left(82.6 \mu \mathrm{g} \mathrm{L} \mathrm{L}^{-1}\right)$ and greater water depths $(8-18 \mathrm{~m})$ were recorded. Finally, the falling water period presented higher values of SRSi $\left(8.2 \mathrm{mg} \mathrm{L}^{-1}\right)$, SRP $\left(94.4 \mu \mathrm{g} \mathrm{L}^{-1}\right)$ and phytoplankton biomass $\left(18.5 \mu \mathrm{g} \mathrm{L} \mathrm{L}^{-1}\right)$ similar to what was recorded during the low water (Table 2).

The first two principal components from PCA ordination explained $68.95 \%$ of the variation in the superficial layer and $65.8 \%$ of the variation at the bottom of the lake. The variables that most contributed to formation of the first principal component in both superficial and bottom waters were conductivity, alkalinity, $\mathrm{CO}_{2}$ and cations (ions axis; Table 3). In superficial waters, formation of the second principal component was strongly influenced by dissolved oxygen concentrations, although ammonia, total suspended solids and water transparency were also important variables. In the bottom layers, dissolved oxygen contributed positively, while COD contributed negatively (oxygen axis). The PCA ordination showed the formation of a north-to-south spatial gradient (most evident in superficial layers) among the four collection points in relation to the distribution of limnological

Table 2 - Averages, standard deviation (SD) and coefficient of variation (CV) of the limnological variables in the superficial and bottom layers of Lake Catalão during the different hydrological periods (low water, rising water, high water and falling water) from Nov/2004 to Aug/2005. Zmix: mixture zone; Cond: electrical conductivity, SRSi: soluble reactive silica, SRP: soluble reactive phosporous, TSS: total suspended solids.

\begin{tabular}{|c|c|c|c|c|c|c|c|c|}
\hline \multirow{3}{*}{ Variables } & \multicolumn{8}{|c|}{ Hydrological Cycle } \\
\hline & \multicolumn{2}{|c|}{ Low water } & \multicolumn{2}{|c|}{ Rising water } & \multicolumn{2}{|c|}{ High water } & \multicolumn{2}{|c|}{ Falling water } \\
\hline & $A v g \pm S D$ & CV & $A v g \pm S D$ & CV & $A v g \pm S D$ & CV & $A v g \pm S D$ & CV \\
\hline Transparency (m) & $0.6 \pm 0.1$ & 16.6 & $1.0 \pm 0.1$ & 13.6 & $0.7 \pm 0.3$ & 41.1 & $0.8 \pm 0.0$ & 6.1 \\
\hline Zmix & $4.1 \pm 2.3$ & 54.5 & $9.0 \pm 6.9$ & 77.0 & $6.3 \pm 7.9$ & 126.2 & $2.5 \pm 0.0$ & 0.0 \\
\hline Depth (m) & $5.4 \pm 3.3$ & 61.5 & $8.5 \pm 3.9$ & 45.4 & $12.8 \pm 3.7$ & 29.0 & $8.0 \pm 2.8$ & 34.5 \\
\hline & \multicolumn{8}{|c|}{ Surface } \\
\hline Temperature $\left({ }^{\circ} \mathrm{C}\right)$ & $31.7 \pm 0.5$ & 1.5 & $30.7 \pm 1.2$ & 3.9 & $29.9 \pm 1.4$ & 4.8 & $31.2 \pm 0.4$ & 1.3 \\
\hline Oxygen $\left(\mathrm{mg} \mathrm{L}^{-1}\right)$ & $4.4 \pm 0.7$ & 16.9 & $3.6 \pm 0.7$ & 19.5 & $2.9 \pm 1.1$ & 35.6 & $2.7 \pm 0.5$ & 17.9 \\
\hline Cond $\left(\mu \mathrm{S} \mathrm{cm}^{-1}\right)$ & $82.3 \pm 39.4$ & 47.9 & $21.9 \pm 8.5$ & 38.9 & $65.7 \pm 1.3$ & 2.0 & $76.2 \pm 4.4$ & 5.8 \\
\hline $\mathrm{pH}$ & $7.1 \pm 0.3$ & 4.3 & $6.3 \pm 0.5$ & 8.4 & $6.8 \pm 0.2$ & 3.5 & $6.8 \pm 0.0$ & 0.7 \\
\hline $\mathrm{CO}_{2}\left(\mathrm{mg} \mathrm{L}^{-1}\right)$ & $40.0 \pm 18.8$ & 47.2 & $15.9 \pm 3.5$ & 22.2 & $33.3 \pm 2.2$ & 6.7 & $39.9 \pm 3.2$ & 8.0 \\
\hline Alcalinity $\left(\mathrm{mgHCO}_{3} \mathrm{~L}^{-1}\right)$ & $47.3 \pm 25.9$ & 54.7 & $12.2 \pm 5.9$ & 48.5 & $38.8 \pm 0.8$ & 2.0 & $41.8 \pm 2.7$ & 6.4 \\
\hline $\mathrm{COD}\left(\mathrm{mg} \mathrm{L}^{-1}\right)$ & $35.4 \pm 5.6$ & 15.9 & $50.6 \pm 4.3$ & 8.6 & $27.5 \pm 1.0$ & 3.5 & $27.8 \pm 1.1$ & 4.1 \\
\hline $\mathrm{BOD}\left(\mathrm{mg} \mathrm{L}^{-1}\right)$ & $2.0 \pm 0.8$ & 40.0 & $1.4 \pm 0.6$ & 43.1 & $1.33 \pm 0.76$ & 57.10 & $1.40 \pm 0.5$ & 35.1 \\
\hline SRSi (mg L-1) & $3.5 \pm 2.2$ & 61.4 & $1.5 \pm 1.5$ & 95.1 & $6.1 \pm 0.1$ & 2.3 & $8.0 \pm 1.2$ & 15.3 \\
\hline Ammonia $\left(\mu \mathrm{g} \mathrm{L}^{-1}\right)$ & $99.0 \pm 35.0$ & 35.3 & $32.8 \pm 14.0$ & 42.6 & $49.6 \pm 62.2$ & 125.3 & $14.3 \pm 1.6$ & 11.0 \\
\hline $\mathrm{N}$-nitrite $\left(\mu \mathrm{g} \mathrm{L}^{-1}\right)$ & $3.0 \pm 4.3$ & 144.3 & $0.3 \pm 0.5$ & 200.0 & $1.2 \pm 0.1$ & 11.6 & $1.0 \pm 0.0$ & 0.0 \\
\hline $\mathrm{N}$-nitrate $\left(\mu \mathrm{g} \mathrm{L}^{-1}\right)$ & $55.7 \pm 15.5$ & 27.8 & $57.3 \pm 35.4$ & 61.8 & $74.9 \pm 44.8$ & 59.8 & $23.6 \pm 1.1$ & 4.8 \\
\hline $\operatorname{SRP}\left(\mu \mathrm{g} \mathrm{L} \mathrm{L}^{-1}\right)$ & $8.6 \pm 9.6$ & 111.8 & $6.9 \pm 7.4$ & 107.7 & $3.7 \pm 1.0$ & 27.2 & $2.1 \pm 2.0$ & 97.9 \\
\hline $\mathrm{Mg}\left(\mathrm{mg} \mathrm{L}^{-1}\right)$ & $1.5 \pm 0.7$ & 47.1 & $0.5 \pm 0.2$ & 53.3 & $1.0 \pm 0.0$ & 3.5 & $1.2 \pm 0.0$ & 3.1 \\
\hline Calcium (mg L-1) & $3.0 \pm 1.0$ & 34.3 & $1.4 \pm 0.5$ & 34.6 & $5.1 \pm 0.3$ & 6.2 & $4.7 \pm 0.2$ & 3.7 \\
\hline Potassium (mg L-1) & $1.2 \pm 0.4$ & 36.4 & $0.7 \pm 0.3$ & 37.8 & $0.9 \pm 0.0$ & 3.7 & $1.1 \pm 0.1$ & 11.5 \\
\hline Sodium (mg L-1) & $4.1 \pm 2.4$ & 59.4 & $1.0 \pm 0.3$ & 25.7 & $2.8 \pm 0.1$ & 2.7 & $4.0 \pm 1.1$ & 28.7 \\
\hline Chla a $\left(\mu \mathrm{g} \mathrm{L}^{-1}\right)$ & $19.1 \pm 5.3$ & 27.6 & $7.9 \pm 4.4$ & 55.9 & $8.3 \pm 2.1$ & 25.2 & $18.5 \pm 2.9$ & 15.7 \\
\hline \multirow[t]{2}{*}{ TSS (mg L-1) } & $31.0 \pm 10.2$ & 32.9 & $30.7 \pm 1.2$ & 3.9 & $29.9 \pm 1.4$ & 4.8 & $31.2 \pm 0.4$ & 1.3 \\
\hline & \multicolumn{8}{|c|}{ Bottom } \\
\hline Temperature $\left({ }^{\circ} \mathrm{C}\right)$ & $30.4 \pm 1.1$ & 3.5 & $28.8 \pm 0.1$ & 0.4 & $28.3 \pm 0.1$ & 0.2 & $28.9 \pm 0.6$ & 1.9 \\
\hline Oxygen (mg L-1) & $2.2 \pm 1.1$ & 51.6 & $0.8 \pm 0.2$ & 29.9 & $2.0 \pm 0.8$ & 38.4 & $0.9 \pm 0.1$ & 13.3 \\
\hline Cond $\left(\mu \mathrm{S} \mathrm{cm}^{-1}\right)$ & $113.5 \pm 69.9$ & 61.6 & $38.4 \pm 10.8$ & 28.1 & $66.7 \pm 4.7$ & 7.1 & $118.3 \pm 28.6$ & 24.2 \\
\hline $\mathrm{pH}$ & $6.8 \pm 0.3$ & 4.4 & $6.3 \pm 0.4$ & 6.2 & $7.0 \pm 0.2$ & 2.9 & $6.8 \pm 0.2$ & 2.4 \\
\hline $\mathrm{CO}_{2}\left(\mathrm{mg} \mathrm{L}^{-1}\right)$ & $58.3 \pm 32.9$ & 56.4 & $26.1 \pm 5.3$ & 20.4 & $36.2 \pm 5.8$ & 15.9 & $61.2 \pm 7.0$ & 11.4 \\
\hline Alcalinity $\left(\mathrm{mgHCO}_{3} \mathrm{~L}^{-1}\right)$ & $58.4 \pm 33.2$ & 56.8 & $18.5 \pm 5.8$ & 31.2 & $40.0 \pm 3.4$ & 8.5 & $50.9 \pm 3.2$ & 6.3 \\
\hline $\mathrm{COD}\left(\mathrm{mg} \mathrm{L}^{-1}\right)$ & $44.4 \pm 14.1$ & 31.8 & $52.5 \pm 1.4$ & 2.6 & $32.1 \pm 3.8$ & 11.9 & $41.5 \pm 3.0$ & 7.3 \\
\hline $\mathrm{BOD}\left(\mathrm{mg} \mathrm{L}^{-1}\right)$ & $1.2 \pm 1.2$ & 94.8 & $0.2 \pm 0.2$ & 115.5 & $0.4 \pm 0.4$ & 96.3 & $0.0 \pm 0.0$ & 0.0 \\
\hline SRSi (mg L-1) & $3.2 \pm 0.7$ & 22.0 & $2.0 \pm 1.1$ & 55.8 & $6.2 \pm 0.2$ & 3.7 & $8.5 \pm 1.3$ & 15.9 \\
\hline Ammonia $\left(\mu \mathrm{g} \mathrm{L}^{-1}\right)$ & $758.7 \pm 1088$ & 143.5 & $43.1 \pm 17.9$ & 41.7 & $80.3 \pm 88.4$ & 110.1 & $406.2 \pm 119.1$ & 29.3 \\
\hline $\mathrm{N}$-nitrite $\left(\mu \mathrm{g} \mathrm{L}^{-1}\right)$ & $1.4 \pm 0.6$ & 45.1 & $0.3 \pm 0.4$ & 173.2 & $0.9 \pm 0.1$ & 12.5 & $11.4 \pm 5.0$ & 43.8 \\
\hline N-nitrate $\left(\mu \mathrm{g} \mathrm{L}^{-1}\right)$ & $59.4 \pm 17.9$ & 30.2 & $47.7 \pm 19.5$ & 40.9 & $90.3 \pm 37.1$ & 41.1 & $22.0 \pm 4.8$ & 22.0 \\
\hline $\operatorname{SRP}\left(\mu \mathrm{g} \mathrm{L}^{-1}\right)$ & $7.4 \pm 9.9$ & 134.5 & $11.3 \pm 2.1$ & 18.4 & $4.2 \pm 0.9$ & 22.2 & $186.7 \pm 72.2$ & 38.7 \\
\hline $\operatorname{Mg}\left(\mathrm{mg} \mathrm{L}^{-1}\right)$ & $1.5 \pm 0.6$ & 39.8 & $0.8 \pm 0.3$ & 35.5 & $1.1 \pm 0.0$ & 4.4 & $1.6 \pm 0.3$ & 17.7 \\
\hline Calcium (mg L-1) & $4.1 \pm 1.8$ & 43.6 & $2.0 \pm 0.5$ & 25.1 & $5.0 \pm 0.2$ & 4.7 & $5.5 \pm 0.2$ & 3.2 \\
\hline Potassium (mg L-1) & $1.2 \pm 0.4$ & 33.3 & $1.2 \pm 0.4$ & 30.3 & $0.9 \pm 0.1$ & 6.3 & $1.2 \pm 0.2$ & 13.7 \\
\hline Sodium $\left(\mathrm{mg} \mathrm{L}^{-1}\right)$ & $3.9 \pm 2.0$ & 50.4 & $1.3 \pm 0.2$ & 19.2 & $2.9 \pm 0.1$ & 2.7 & $4.1 \pm 1.0$ & 24.9 \\
\hline
\end{tabular}


Table 3 - Correlation among the limnological variables sampled in Lake Catalão with the two first principal components (PCA; sublined coefficients are important for the formation of a principal component). * Percentage explained for each axis. Chemical (COD) and biological (BOD) oxygen demand; SRSi: soluble reactive silica; SRP: soluble reactive phosphorous; TSS: total suspended solids.

\begin{tabular}{|c|c|c|c|c|}
\hline \multirow{3}{*}{ Variables } & \multicolumn{2}{|c|}{ Surface } & \multicolumn{2}{|c|}{ Bottom } \\
\hline & Axis 1 & Eixo 2 & Axis 1 & Axis 2 \\
\hline & $50.7 \% *$ & $18.2 \% *$ & $46.7 \%{ }^{*}$ & $19.2 \% *$ \\
\hline Temperature $\left({ }^{\circ} \mathrm{C}\right)$ & 0.1230 & 0.1996 & -0.03418 & 0.3196 \\
\hline Oxygen (mg L-1) & -0.004132 & 0.4703 & -0.1200 & 0.5024 \\
\hline Electrical Conductivity $\left(\mu \mathrm{S} \mathrm{cm}^{-1}\right)$ & 0.3187 & 0.04853 & 0.3423 & -0.01337 \\
\hline $\mathrm{pH}$ & 0.2434 & 0.1554 & 0.1586 & 0.2979 \\
\hline $\mathrm{CO}_{2}\left(\mathrm{mg} \mathrm{L}^{-1}\right)$ & 0.3117 & 0.02351 & 0.3486 & -0.003569 \\
\hline Alcalinity $\left(\mathrm{mgHCO}_{3}{ }^{-\mathrm{L}^{-1}}\right)$ & -0.3096 & 0.08474 & 0.3279 & 0.1688 \\
\hline $\operatorname{COD}\left(\mathrm{mg} \mathrm{L}^{-1}\right)$ & -0.2663 & 0.2064 & 0.008791 & -0.4663 \\
\hline SRSi $\left(\mathrm{mg} \mathrm{L}^{-1}\right)$ & 0.2551 & -0.2900 & 0.2500 & 0.07551 \\
\hline Ammonia $\left(\mu \mathrm{g} \mathrm{L}^{-1}\right)$ & 0.1105 & 0.3409 & 0.2269 & -0.1091 \\
\hline $\mathrm{N}$-nitrite $\left(\mu \mathrm{g} \mathrm{\textrm {L } ^ { - 1 } )}\right.$ & 0.1777 & 0.1518 & 0.2217 & -0.08854 \\
\hline $\mathrm{N}$-nitrate $\left(\mu \mathrm{g} \mathrm{L}^{-1}\right)$ & -0.1019 & 0.2154 & -0.1924 & 0.3774 \\
\hline $\operatorname{SRP}\left(\mu \mathrm{g} \mathrm{L}^{-1}\right)$ & -0.09611 & 0.2090 & 0.2161 & -0.1688 \\
\hline $\mathrm{Mg}\left(\mathrm{mg} \mathrm{L}^{-1}\right)$ & 0.3116 & 0.0892 & 0.3341 & 0.09455 \\
\hline Calcium (mg L-1) & 0.2355 & -0.2778 & 0.3141 & 0.1344 \\
\hline Potassium (mg L-1) & 0.3007 & 0.03141 & 0.2421 & -0.1786 \\
\hline Sodium (mg L-1) & 0.3036 & 0.06837 & 0.3120 & 0.2353 \\
\hline Chla a $\left(\mu \mathrm{g} \mathrm{L}^{-1}\right)$ & 0.2257 & 0.1402 & - & - \\
\hline TSS (mg L-1) & -0.1883 & 0.3349 & - & - \\
\hline Transparency (m) & -0.1005 & -0.3552 & - & - \\
\hline
\end{tabular}

variables. This gradient was represented by the sequential placement of the collection points (A, B, C and D) along the PCA axes (Figure 3). During the low water, rising water and falling water periods the gradient appeared associated with the first principal component and tended to increase in a north-south direction among the different collection points. At high water, the gradient followed the second axis and decreased inversely as the collection points increased in distance from the Negro River. The PCA grouped the samples by hydrological period, except for the bottom samples during the low water period. The first principal component showed dilution of the waters from the low water to the rising water and enrichment from the rising water to high water, and, in lower proportion, from high water to falling water (Figure 3).

During the low water period the analysis of multivariate dispersion pointed to a high variability in limnological features between the four collections points, in both surface and bottom layers (Figure 4). From this season, there was a general tendency of spatial homogeneization of limnological conditions in the two layers in the following periods, with some differences in the pattern between the two layers. In the surface layer, the limnological homogeneity between the points tended to increase until reaching its maximum value in the falling period (Figure 4a; Appendix A), while in the bottom layer the homogeneization reached its maximum value in the rising waters and remained at that level until the end of the study (Figure 4b; Appendix A).

The central region of Lake Cataláo presented thermal stratification during the low water (thermocline at a depth of $7 \mathrm{~m}$ ) and falling water (thermocline at $2.5 \mathrm{~m}$ ), with the thermoclines forming below the depths affected by daily heating and cooling. Conversely, during high water, complete destratification occurred. During the rising water period, modest superficial heating occurred, causing some thermal instability (Figure 5a, 5b, 5c, 5d). Partial circulation occurred in superficial waters during the low water $(\approx 3-4 \mathrm{~m})$, falling water $(\approx 2-2.5 \mathrm{~m})$ and rising water $(\approx 4-5 \mathrm{~m}$, during the night on the first day), while complete circulation occurred during the high water period (Figure 5a, 5b, 5c, 5d).

The highest oxygen concentrations were always recorded in the afternoon (between 3:00 and 6:00 p.m.) in the first meter from the surface, except during the high water period. While daily variations in dissolved oxygen accompanied the superficial thermal gradients, the vertical dissolved oxygen distribution was characterized by stratification during low water, rising water and falling water (reaching hypoxic conditions in the hypolimnion) and homogenous distribution in the water column at high water (Figure 5e, 5f, 5g, 5h). During the entire study, no dissolved oxygen saturation was recorded at any of the collection points (maximum oxygen saturation: $87.3 \%$ during falling water). 

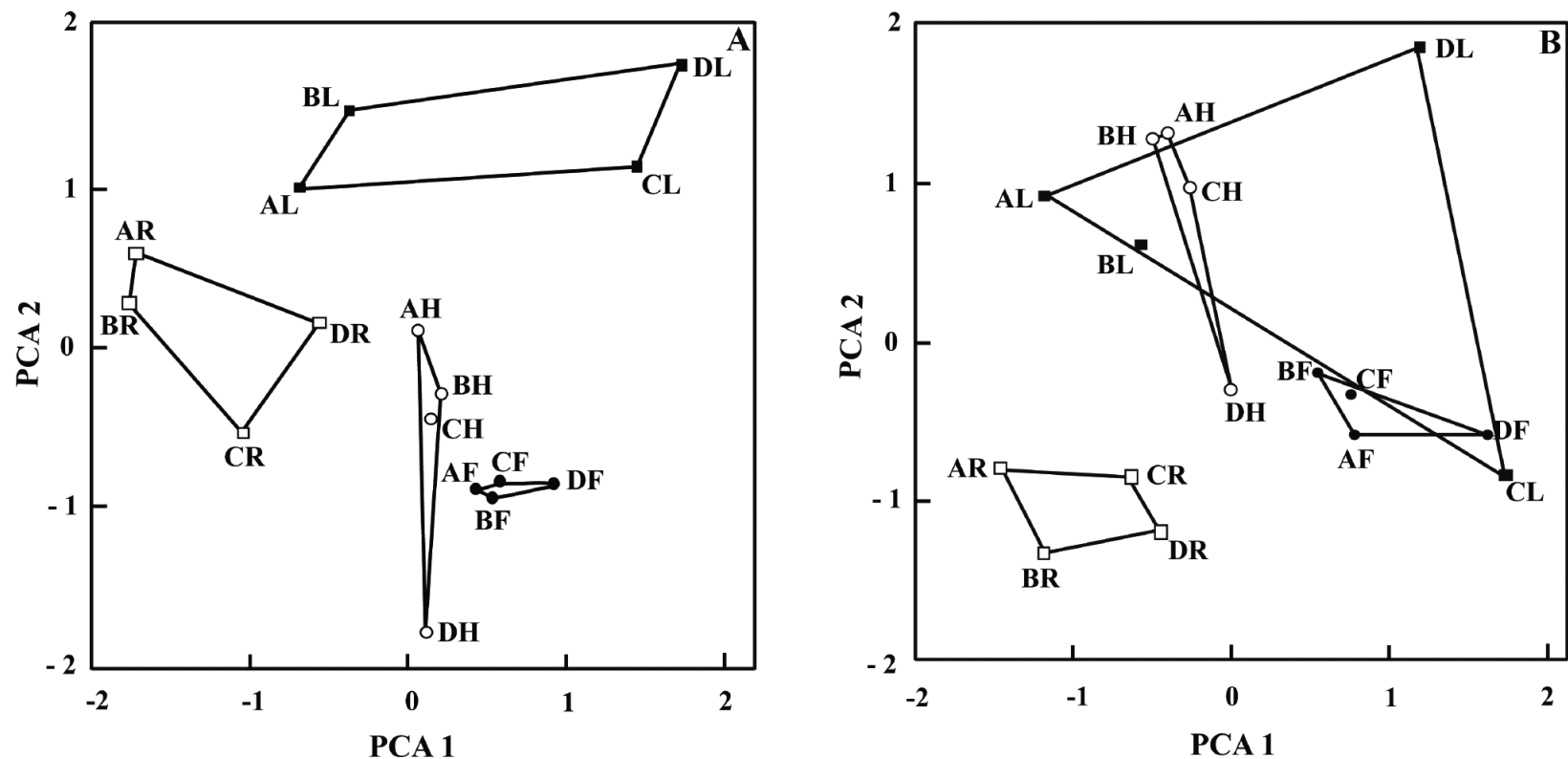

Figure 3 - Principal Components Analysis (PCA) synthesizing the data of the limnological variables sampled at the surface (A; left panel) and at the bottom (B; right panel) of Lake Catalão, from Nov/04 to Aug/05. The filled squares represent the low water, empty squares the rising water period, empty circles the high water period, and filled circles the falling water period. The first letter represents the collection points (A, B, C and D), which sequentially represent a gradient of distances from the Negro River, and the second letter refers to the period (L: low water, R: rising water, $\mathrm{H}$ : high water and F: falling water). The geometric figures grouped the collection points by hydrological period.
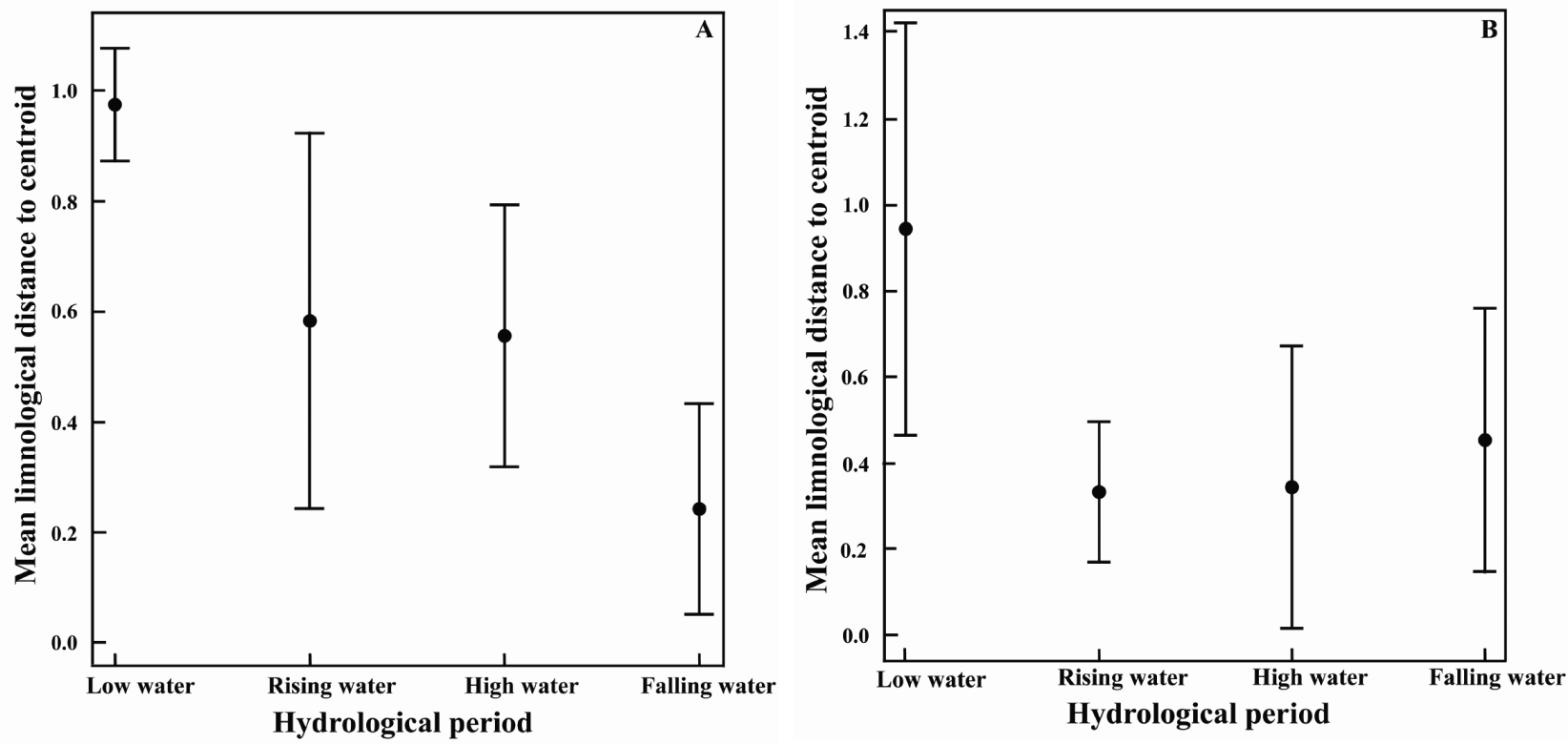

Figure 4 - Multivariate dispersion analysis for surface (A) and bottom (B) layers of the study area. Filled dots represent the mean limnological distances of the collection points to the centroid in the multivariate limnological space for each of the four hydrological periods. High values of distances mean high dispersion of the points from its centroid (i.e. a low limnological homogenization). The lines delimit the $95 \%$ confidence interval. 

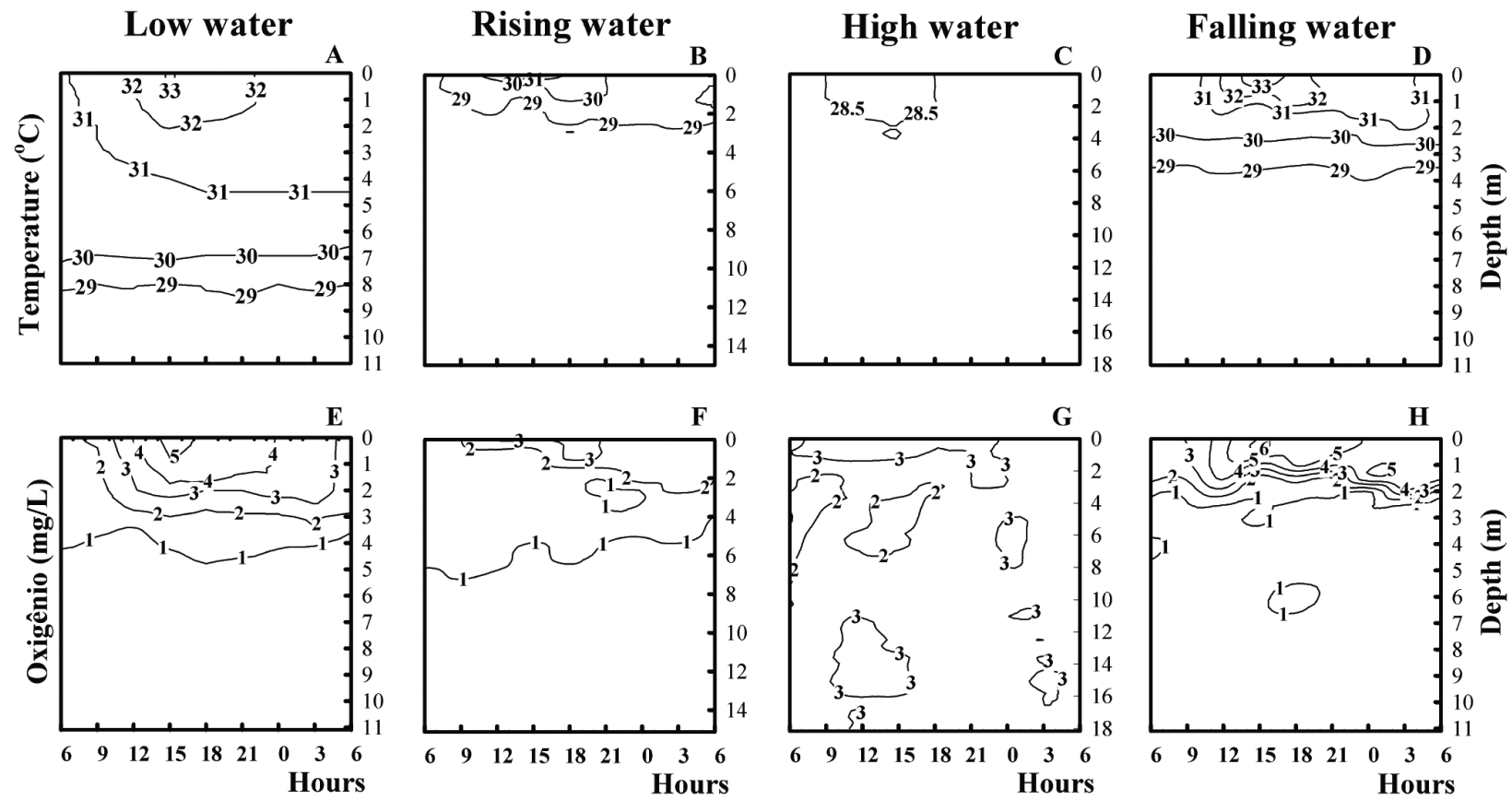

Figure 5 - Variations in daily profiles of temperature $\left({ }^{\circ} \mathrm{C}\right)$ and dissolved oxygen $\left(\mathrm{mg} \mathrm{L}^{-1}\right)$ of Lake Catalão during low water $(A$ and $E)$, rising water $(B$ and $F)$, high water ( $C$ and $G$ ) and falling water ( $D$ and $H$ ) during the period from Nov/2004 to Aug/2005. Profiles of temperature ( $A, B, C$ e D) and dissolved oxygen (E, F, G e H).

Profiles of conductivity and $\mathrm{pH}$ did not present large daily variations. However, vertical profiles showed that conductivity values in the hypolimnion were $33-50 \%$ higher than in the epilimnion, except during high water when vertical homogeneity was established.

\section{DISCUSSION}

Microbial activity represents an important source of ions for aquatic ecosystems (Junk 1997; Carvalho et al. 2005). In lakes, the processes of microbial decomposition and mineralization depend on allochthonous and autocthonous inputs of organic material (OM) (Kritzberg et al. 2004). Therefore, the availability of organic material sources from flooded forest and aquatic macrophytes should be an important factor in the spatial distribution of ions and $\mathrm{CO}_{2}$ in certain lakes. In Lake Cataláo, the tendency for ion concentrations to augment in relation to increasing distance from the Negro River during the low water, rising water and falling water periods is most likely due to organic material inputs from seasonally flooded forest and stands of aquatic macrophytes, which increase in availability in a north-south direction from the Negro River. During high water, however, a spatial gradient tendency associated with dissolved oxygen levels should be treated with some caution. Dissolved oxygen is a very dynamic variable, demonstrated by large variations occurring spatially on a daily basis in Amazon floodplain waters (Sánchez-Botero et al. 2001). Therefore, in order to verify a spatial gradient tendency indicated in this study, it would be prudent to apply an experimental design with strict criteria and increase sampling replications.

Seasonally, the large changes in limnological conditions observed in Lake Cataláo were directly associated with water levels in the lake, reflecting the influence of hydrological connectivity. Each one of the hydrological periods presented distinct characteristics, which were useful in separating differences in limnological conditions.

The low water is known as the hydrological period when floodplain lakes are most isolated from the main river channel (Forsberg et al. 1988). Hence, the limnological characteristics of lacustrine systems during this period tends to be controlled by autogenic events (production, decomposition, herbivory and resuspension of sediments; Tockner et al. 1999; Carvalho et al. 2001) and by influence of the local drainage basin (Forsberg et al. 1988). In Lake Cataláo, the lack of small tributaries indicates that autogenic events are the principal controlling influence in regard to variations in limnological conditions during this period. Nutrient cycling via microbial activity and the resuspension of sediments in the shallowest parts of the lake (collection point D) appeared to strongly influence high values of conductivity, alcalinity, $\mathrm{CO}_{2}$, cations and ammonia (collection points $\mathrm{C}$ and $\mathrm{D}$ ), as suggested by studies in other floodplain lakes (Furch 1984; Forsberg et 
al. 1988). The decomposition of aquatic macrophytes is an important example of how microbial activity contributes to ionic composition in floodplain lakes, which tends to occur during the falling water and low water periods (Melack and Forsberg 2001), liberating significant quantities of dissolved substances into the water (Howard-Williams and Junk 1976; Carvalho et al. 2005).

As the water level increased from the low water through rising water to peak flood, the lake's independence and isolation decreased while fluvial input from the Negro and Solimóes rivers increased. During rising water, increased dilution in the lake, in comparison with the low water period, indicated an influx of acidic and low-nutrient water from the Negro River. This was evidenced by the conductivity values during rising water $\left(13-45 \mu \mathrm{S} \mathrm{cm} \mathrm{cm}^{-1}\right)$, which would have been much higher had there also been fluvial input from the Solimóes River, which presented conductivity values $>60 \mu \mathrm{S}$ $\mathrm{cm}^{-1}$. Then at high water, it appears that the lake received an input of nutrients from the Solimóes River, as shown by an increase in conductivity $\left(65 \mu \mathrm{S} \mathrm{cm}^{-1}\right)$ and $\mathrm{N}$-nitrate; the latter demonstrating enrichment of the waters of the lake (Forsberg 1984). The processes of enrichment and dilution of floodplain lake waters depend on the chemical characteristics of both the lake and contributing rivers (Furch 1984; Thomaz et al. 1997; Rodrigues and Bicudo 2001; Taniguchi et al. 2004).

Another common occurrence during rising and peak water periods involves the reduction in dissolved oxygen concentration in floodplain lakes, which is generally attributed to the high oxygen demand of invading waters (Townsend 2006) and a dilution of phytoplanktonic biomass (Rodrigues 1994). Our results suggest the action of similar mechanisms in Lake Cataláo. Almeida and Melo (2011), in a study of phytoplankton community structure in the same lake at low and high water, encountered lower populacional density at peak flood, demonstrating the influence of the dilution mechanism with respect to lower dissolved oxygen levels during periods of fluvial influx.

After peak flood, lake water levels and the influence of fluvial processes began to diminish (Forsberg et al. 1988), while autogenic mechanisms became reactivated to exercise more control over limnological characteristics in the lake. For example, the increase in ionic concentrations during falling water showed evidence of an increase in metabolic activity of the lacustrine system, while a reduction in concentrations of nitrate, ammonia and SRP in the epilimnion, when compared with the peak water period, indicated significant biological absorption. Although the levels of phytoplankton biomass were similar between the falling water and low water periods, the low dissolved oxygen levels encountered in the superficial water layers during falling water may have been related to moderate incident light radiation $(892.3 \pm 377.2$ $\left.\mu \mathrm{mol} \mathrm{m} \mathrm{s}^{-1}\right)$ recorded on the sampling day. When daily fluxes in limnological variables were conducted the following day, the average active photosynthetic radiation reached $1415.8 \pm$ $427.3 \mu \mathrm{mol} \mathrm{m}^{-2} \mathrm{~s}^{-1}$, which corresponded with higher values of dissolved oxygen encountered in the superficial layers.

In relation to the effect of fluvial influx on aquatic habitats in floodplain lakes, Thomaz et al. (2007) emphasized the homogenizing influence brought on by flooding. According to these authors spatial homogeneity in floodplain lakes tends to be higher during fluvial influx, due to an increase in connectivity between aquatic habitats. Conversely, during falling water and low water periods, spatial homogeneity decreases as lakes become more isolated from the main river channel and local forces enact increasing influence over limnological conditions within the lacustrine system. In part, the results obtained in the present study corroborated the findings of Thomaz et al. (2007). The largest limnological heterogeneity among habitats was encountered in the low water. In superficial water layers, differences in organic material sources, availability and their influence on microbial metabolism (Kritzberg et al. 2004) appeared to be the key factors responsible for lateral dissimilarity in the lake during this period. In the bottom layers, organic material variability and differences in water depth and thermal patterns appeared to be the principal factors contributing to the enormous heterogeneity encountered among collection points in the lake. Collection points A, B and D presented lower water depths $(2.5-4 \mathrm{~m})$ and an apparent lack of thermal stratification during the low water period (without a large accumulation of ions). In contrast, point $\mathrm{C}$ presented greater depth (11 $\mathrm{m})$ and inefficient mixture agents (e.g. winds) during low water, contributing to persistent thermal stratification, deoxygenation and accumulation of a large quantity of ions in the hypolimnion.

During rising water, greater fluvial connectivity among the collection points appeared to explain the increase in homogeneity of limnological variables, in comparison with the low water. The action of water currents associated with fluvial influx, aided by frequent storms during the rising water period, appears to have disrupted the thermal isolation registered at point $\mathrm{C}$ during the low water and the subsequent accumulation of ions in the hypolimnion, resulting in more uniform conditions encountered in the bottom layers of the lake.

Spatial similarity in the lake during peak flood, although being higher than during the low water, was not as high as predicted for this phase of the hydrological cycle. In general, due to more intense fluvial influx, greater homogeneity of water bodies was expected. The lower level of similarity was mainly associated with low dissolved oxygen levels registered at point $\mathrm{D}$, when compared with the other collection points. 
Point D presented an abundant proliferation of aquatic macrophytes, which tended to serve as a physical barrier to water circulation, thereby interfering with oxygen levels (Bonetto et al. 1984). Furthermore, dense stands of aquatic macrophytes can cause large daily and depth-based variations in dissolved oxygen levels (Sánchez-Botero et al. 2001), due to changes in respiration rates and levels of primary productivity (see Wilcock et al. 1999). Therefore, both the presence of aquatic macrophytes and the isolation provided by the floodplain forest bordering point $\mathrm{D}$ appears to have propitiated oxygen level variations in the lake, which, in turn, affected spatial similarity. It is important to note that the first principal PCA component indicated large homogeneity during high water.

Almeida and Melo (2009), studying the variations in limnological parameters in Lake Catalão at high and low water, found greater spatial similarity during peak flood. However, in the present study, the large spatial similarity encountered in superficial waters occurred in the falling water period, when compared with other hydrological periods. This may be due to persistent thermal stratification, which appeared to occur at similar depths in all the collection points. The large mass of water moving out of the lake in the direction of the river is another factor which likely increased spatial similarity during this period. The thermal isolation of the epilimnion, by restricting exchange with the hypolimnion, allowed for mixing patterns in a similar way among all the collection points, which appeared to promote more homogeneous limnological conditions in superficial layers. At the bottom of the lake, processes involving liberation of ions (Melack and Fisher 1990) and the availability of organic matter, principally at point $\mathrm{D}$, appear to have strengthened the limnological differences among the collection points.

Mixing patterns in floodplain lakes have been attributed principally to the daily stratification cycle and the annual variation in water level, which are driven by the hydrological regime of the main river channel (Tundisi et al. 1984). The results of the present study indicate a predominating atelomixis pattern, defined as an incomplete vertical mixing of stratified water masses, which, in turn, homogenizes water layers (see Barbosa and Padisák 2002). This phenomenon could explain the continuous partial water circulation and daily variations in mixing depth observed in Lake Cataláo, which was permanently connected to the Negro River over the course of the hydrological cycle. Complete mixing of the water column only occurred during high water, when a period of atmospheric cooling (locally known as friagem) brought much cooler temperatures to the region of Lake Catalão $\left(24.5-29 \cdot 0^{\circ} \mathrm{C}\right)$. Besides reducing air temperature, this phenomenon also usually intensifies wind action (Oliveira et al. 2004), which increases mixing of the water column, even in deep lakes (Tundisi et al. 1984). Almeida and Melo (2009), in a limnological study of the same lake, observed oligomitic tendencies during high water and polimitic tendencies during low water; the latter occurring when the lake was isolated from the Negro River, while presenting a depth of 6 meters.

\section{CONCLUSIONS}

Similar to other floodplain lakes, the limnological conditions of Lake Catalão are principally controlled by seasonal, and to a lesser extent, spatial variations in the hydrological regime of the main river channels. The Negro River appears to exert the main influence during the rising water period, while the Solimóes River is the principal controlling river during peak water. Although Lake Cataláo receives large quantities of both black, acidic water from the Negro River and sediment-filled water from the Solimóes River, the physical and chemical characteristics of the lake are more similar to those of the Solimóes (várzea lake) than the Negro (blackwater lake). PCA grouped the seasonal collections by hydrological period, showing the formation of a north-south spatial gradient within the lake in relation to limnological variables. Multivariate dispersion analysis based on distance-to-centroid method demonstrated an increase in similarity over the course of the hydrological cycle as the lake was inundated in response to the flood pulse of the main river channels. However, the largest spatial homogeneity in the lake was observed in the epilimnion layer, during the falling water period. The daily analysis of variation indicated an oligomitic pattern during the period in which the lake was permanently connected to the Negro River.

\section{ACKNOWLEDGEMENTS}

The authors would like to thank the Conselho Nacional de Desenvolvimento Científico e Tecnológico (CNPq) for funding of this work, including the master scholarship to the first author, and also the Aquatic Biology Department at the Instituto Nacional de Pesquisas da Amazônia (INPA) in Manaus, Brazil for logistical support. Special thanks to José Carlos Paula Raposa and André Nilson Neves de Oliveira for help with field collections and laboratorial analyses, Vivian Campos de Oliveira for preparation of map and José Edivaldo Chaves and Soil Laboratory of the INPA for ions analyses. JGB received a doctoral scholarship from the Fundaçáo de Amparo à Pesquisa do Estado do Amazonas (FAPEAM). 


\section{REFERENCES}

Almeida, F.F.; Melo, S. 2009. Consideraçóes limnológicas sobre um lago da planície de inundação amazônica (lago Cataláo-Estado do Amazonas, Brasil). Acta Scientiarum Biological Sciences, 3: 387-395.

Almeida, F.F.; Melo, S. 2011. Estrutura da Comunidade fitoplanctônica de um lago de inundaçáo amazônico (Lago Catalão, Amazonas, Brasil). Neotropical Biology and Conservation, 6:112-123.

Anderson, M.J.; Ellingsen, K.E.; McArdle, B.H. 2006. Multivariate dispersion as a measure of beta diversity. Ecology Letters, 9: 683-693.

Barbosa, F.A.R.; Padisák J. 2002. The forgotten lake stratification pattern of atelomixis, and its ecological importance. Verhandlungen der internationalen vereinigung für theroetische and angwandte limnologie, 28: 1385-1395.

Bense, K; Falls, C.F.; Hobson, L.A. 1963. A gravimetric method for determining suspended matter using Milipore filters. Deep Sea Research, 10:639-642.

Bonetto, C.A.; Zalocar Y.; Lancelle, H.G. 1984. A limnological study of an oxbow-lake covered by Eichhornia crassipes in the Paraná River. Verhandlungen des Internationalen Verein Limnologie, 22: 1315-1318.

Carvalho, P.; Bini, L.M.; Thomaz, S.M.; Oliveira, L.G.; Robertson, B.; Tavechio, W.L.G.; Darwich, A.J. 2001. Comparative limnology of South American floodplain lakes and lagoons. Acta Scientiarum, 23: 265-273.

Carvalho, P.; Thomaz, S.M.; Bini, L.M. 2005. Effects of temperature on decomposition of a potential nuisance species: The submerged aquatic macrophyte Egeria najas planchon (Hydrocharitaceae). Brazilian Journal of Biology, 65:51-60.

Darwich, A.J.; Aprile, F.M.; Robertson, B.A. 2005. Variáveis limnológicas: contribuição ao estudo espaço-temporal de águas pretas amazônicas. In: Santos-Silva, E.N.; Aprile, F.M.; Scudeller, V.V.; Melo, S. (Eds.). BioTupé: meio físico, diversidade biológica e sociocultural do Baixo Rio Negro Amazônia Central. Instituto Nacional de Pesquisas da Amazônia, Manaus, Amazonas, p. 20-33.

Fantin-Cruz, I.; Loverde-Oliveira, S.M.; Girard, P. 2008. Caracterização morfométrica e suas implicaçóes na limnologia de lagos do Pantanal Norte. Acta Scientiarum. Biological Sciences, 30:133-140.

Forsberg, B.R.1984. Nutrient processing in Amazon floodplain lakes. Verhandlungen der Internationalen Vereinigung für Theoretische und Angewandte Limnologie, 22:1294-1298.

Forsberg, B.R. Devol, A.H.; Richey, J.E.; Martinelli, L.A.; Santos, H. 1988. Factors controlling nutrient concentrations in Amazon floodplain lakes. Limnology and Oceanography, 33:41-56.

Furch, K. 1984. Water chemistry of the Amazon basin: The distribution of the chemical elements among freshwaters, p. 167-199. In: Sioli. H. (Ed.). The Amazon. Limnology and landscape ecology of a mighty tropical river and its basin. Dr. W. Junk. Publishers, Dordrecht, Holanda do Sul.
Golterman, H.L.; Clymo, R.S.; Ohnstad, M.A.M. 1978. Methods for physical and chemical analysis of fresh waters. IBP Handbook $\mathrm{n}^{\circ} 8,2^{\circ}$ ed. Blackwell Publications, Oxford. $213 \mathrm{pp}$.

Goulding, M. 1980. The fishes and the forest. Exploration in Amazonian natural history. University of California Press, Berkeley, CA, USA. 280 pp.

Hammer, Ø.; Harper, D.A.T.; Ryan, P.D. 2001. PAST: Paleontological Statistics Software Package for Education and Data Analysis. Palaeontologia Electronica, 4: 9 (http://palaeo-electronica. org/2001_1/past/issue1_01.htm). Acesso em 5/5/2010.

Howard-Williams, C.; Junk, W.J. 1976. The decomposition of aquatic macrophytes in the floating meadows of a central Amazonian várzea lake. Biogeographica, 7:115-123.

Junk, W.J. 1997. Structure and function of the large Central Amazonian river floodplains: Synthesis and Discussion, p. 455468. In: Junk W.J. (Ed.). The Central Amazon Floodplain. v. 126. Springer-Verlag Berlin Heidelberg, Germany.

Junk, W.J.; Barley, P.B.; Sparks, R.E. 1989. The flood pulse concept in river floodplain systems. Canadian Special Publication of Fisheries and Aquatic Sciences, 106:110-127.

Junk, W.J.; Furch, K. 1980. Química da água e macrófitas aquáticas de rios e igarapés na Bacia Amazônica e nas áreas adjacentes. Parte I: Trecho Cuiabá - Porto Velho - Manaus. Acta Amazonica, 10: 611-633.

Junk, W.J.; Welcomme, R.L. 1990. Floodplains, p. 491-524. In: Patten, B.C. (Ed.). Wetlands and shallow continental water bodies. SPB Academic Publishing, The Hague, South Holland.

Koroleff, F. 1970. Direct determination of ammonia in natural waters as indophenols blue. ICES Interlaboratory Report, 3:19-22.

Kritzberg, E.S.; Cole, J.J.; Pace, M.L.; Granéli W.; Bade, D.L. 2004. Autochthonous versus allochthonous carbon sources of bactéria: Results from whole-lake ${ }^{13} \mathrm{C}$ addition experiments. Limnology and Oceanography, 49: 588-596.

Legendre, P.; Legendre, L. 1998. Numerical Ecology. Second Edition, Elsevier Science B.V., Amsterdam, The Netherlands. 853 pp.

Leite, R.G.; Silva, J.V.V.; Freitas, C.E. 2006. Abundância e distribuição das larvas de peixes no Lago Cataláo e no encontro dos rios Solimóes e Negro, Amazonas, Brasil. Acta Amazonica, 36: 557-562.

Lesack, L.F.; Melack, J.M. 1995. Flooding hydrology and mixture dynamics of lake water derived from multiple sources in an Amazon floodplain lake. Water Resources Research, 31:329-345.

MacIntyre, S.; Melack, J.M. (1988). Frequency and depth of vertical mixing in an Amazon floodplain lake (L.Calado, Brazil). Verhandlungen des Internationalen Verein Limnologie, 23:80-85.

Melack, J.M.; Fisher, T.R. 1990. Comparative limnology of tropical floodplain lakes with an emphasis on the Central Amazon. Acta Limnologica Brasiliensia, 3:1-48.

Melack, J.; Forsberg, B.R. 2001. Biogeochemistry of Amazon floodplain lakes and associated wetlands, p. 235-274. In: McClain, M.E.; Victoria, R.L.; Richey, J.E. (Eds.). The biogeochemistry of the amazon basin. Oxford University Press, New York, New York. 
Naselli-Flores, L. 2000. Phytoplankton assemblages in twenty-one Sicilian reservoirs: relationships between species composition and environmental factors. Hydrobiologia, v. 424:1-11.

Oksanen, J.; Blanchet, F.G.; Kindt, R.; Legendre, P.; O’Hara, R.B.; Simpson, G.L.; Solymos, P.; Stevens, M.H.H.; Wagner, H. 2010. vegan: Community Ecology Package. R package version 1.17-3. http://CRAN.R-project.org/package=vegan.

Oliveira, P.J.; Rocha, E.J.P.; Fisch, G.; Kruijt, B.; Ribeiro, J.B.M. 2004. Efeitos de um evento de friagem nas condiçóes meteorológicas da Amazônia: um estudo de caso. Acta Amazonica, 34: 613-619.

Panosso, R.F. Muehe, D.; Esteves, F.A. 1995. Morphological characteristics of an Amazon floodplain lake (Lake Batata, Pará State, Brazil). Amazoniana, 8: 245-258.

Queiroz, M.M.A., Horbe, A.M.C., Seyler, P.; Moura, C.A.V. 2009. Hidroquímica do rio Solimôes na região entre Manacapuru e Alvarães- Amazonas - Brasil. Acta Amazonica, 39: 941-950.

R Development Core Team. 2010. R: A language and environment for statistical computing. R Foundation for Statistical Computing, Vienna, Austria. URL http://www.R-project.org.

Rodrigues, L.; Bicudo, D.C. 2001. Limnological characteristics comparisson in three systems with different hydrodynamic regime in the upper Paraná River Floodplain, Brazil. Acta Limnologica Brasiliensia, 13: 39-49.

Rodrigues, M.S. 1994. Biomassa e produção fitoplanctônica do lago Camaleão (Ilha da Marchantaria, Amazonas). Tese de Doutorado, Instituto Nacional de Pesquisas da Amazônia/Universidade Federal do Amazonas, Manaus, Amazonas. 200 pp.

Sánchez-Botero, J.I. Garcez, D.S. Lobón-Cerviá, J. 2001. Oxigênio dissolvido e temperatura em lagos da região de Ati Paraná-Solimões, Amazônia Central, Brasil. Acta Limnologica Brasiliensia, 13: 45-51.
Sioli, H. 1984. The amazon and its main affluents: hydrography, morphology of the river courses, and river types, p. 127-165. In: Sioli, H. (Ed.). The Amazon: Limnology and Landscape Ecology of a Mighty Tropical River and its Basin. Dr. W. Junk. Publishers, Dordrecht, South Holland.

Sippel, S.J.; Hamilton, S.K.; Melack, J.M. 1992. Inundation area and morphometry of lakes on the Amazon River floodplain, Brazil. Archiv für Hydrobiologie, 123: 385-400.

Taniguchi, G.M.; Bicudo, D.C.; Sennab, P.A.C. 2004. Abiotic variables in littoral-limnetic gradient of an oxbow lake of MogiGuaçu River floodplain, southeastern, Brazil. Brazilian Archives of Biology and Technology, 47: 961-971.

Thomaz, S.M.; Bini, L.M.; Bozelli, R.L. 2007. Floods increase similarity among aquatic habitats in river-floodplain systems. Hydrobiologia, 579:1-13.

Thomaz, S.M.; Roberto, M.C.; Bini, L.M. 1997. Caracterização limnológica dos ambientes aquáticos e influência dos níveis fluviométricos, p. 73-102. In: Vazzoler, A.E.A.M.; Agostinho, A.A. and Hahn, N.S. (Eds.). A planície de inundação do alto rio Paraná: aspectos físicos, biológicos e socioeconômicos. Universidade Estadual de Maringá, Maringá, Paraná.

Tockner, K.; Pennetzdorfer, D.; Reiner, N.; Schiemer, F.; Ward, J.V. 1999. Hydrological connectivity, and the exchange of organic matter and nutrients in a dynamic river-floodplain system (Danube, Austria). Freshwater Biology, 41: 521-535.

Townsend, S.A. 2006. Hydraulic phases, persistent stratification, and phytoplankton in a tropical floodplain lake (Mary River, northern Australia). Hydrobiologia, 556:163-179.

Tundisi, J.G.; Forsberg, B.R.; Devol, A.H.; Zaret, T.M.; Tundisi, T.M.; Santos, A.; Ribeiro, J.S.; Hardy, E.R. 1984. Mixing patterns in Amazon Lakes. Hydrobiologia, 108:3-15.

Wilcock, R.J.; Champion, P.D.; Nagels, J.W.; Croker, G.F. 1999. The influence of aquatic macrophytes on the hydraulic and physic-chemical properties of a New Zealand low land stream. Hydrobiologia, 416: 203-214.

Recebido em 28/09/2012

Aceito em 06/06/2013 
ACTA

Seasonal and spatial variations in limnological conditions of a

floodplain lake (Lake Catalão) connected to both the Solimões and

AMAZONICA

Negro Rivers, Central Amazonia

Appendix A - Distances to the centroids of the limnological variables during each hydrological period calculated by the Euclidean index after standardization of variables by its maximum value. The letters $A, B, C$ and $D$ represent the four different collection points.

\begin{tabular}{ccccccccc}
\hline \multirow{2}{*}{$\begin{array}{c}\text { Collections } \\
\text { points }\end{array}$} & \multicolumn{4}{c}{ Surface } & \multicolumn{5}{c}{ Bottom } \\
\cline { 2 - 9 } & $\begin{array}{c}\text { Low } \\
\text { water }\end{array}$ & $\begin{array}{c}\text { Rising } \\
\text { water }\end{array}$ & $\begin{array}{c}\text { High } \\
\text { water }\end{array}$ & Falling water & Low water & $\begin{array}{c}\text { Rising } \\
\text { water }\end{array}$ & High water & $\begin{array}{c}\text { Falling } \\
\text { water }\end{array}$ \\
\hline Site A & 0.97 & 0.50 & 0.55 & 0.25 & 1.06 & 0.43 & 0.26 & 0.23 \\
Site B & 0.92 & 0.59 & 0.35 & 0.27 & 0.57 & 0.23 & 0.35 & 0.55 \\
Site C & 0.93 & 0.37 & 0.68 & 0.08 & 1.28 & 0.26 & 0.14 & 0.34 \\
Site D & 1.07 & 0.88 & 0.65 & 0.37 & 0.87 & 0.40 & 0.63 & 0.67 \\
\hline Mean \pm 1 SD & $0.97 \pm 0.06$ & $0.58 \pm 0.21$ & $0.55 \pm 0.15$ & $0.24 \pm 0.12$ & $0.94 \pm 0.30$ & $0.33 \pm 0.10$ & $0.34 \pm 0.21$ & $0.45 \pm 0.20$ \\
\hline
\end{tabular}


